\title{
Penerapan Supervisi Kunjungan Kelas untuk Meningkatkan KBM di Sekolah Binaan Semester Genap Tahun 2017/2018 Di Kabupaten Kuantan Singingi
}

\author{
Syamsuwir $^{1}$ \\ Dinas Pendidikan dan Olah Raga Kabupaten Kuantan Singingi, Indonesia \\ syamsuwir@gmail.com \\ Marzuki $^{2}$ \\ Sekolah Tinggi Agama Islam Sulthan Syarif Hasyim Siak, , Indonesia \\ marzuki@gmail.com
}

\begin{abstract}
Abstrak
Pada prinsipnya supervisi merupakan sebuah upaya yang dilakukan oleh supervisor untuk membantu guru dalam meningkatkan dan mengembangkan kegiatan belajar mengajar (KBM). Membantu dalam pengertian untuk memecahkan kesulitan yang dialami oleh guru selama melaksanakan KBM. Disatu sisi mengembangkan kegiatan KBM yang sudah baik. Untuk membantu tersebut supervisor melakukan supervisi kunjungan kelas dengan harapan dapat melakukan pengamatan secara langsung. Temuan bersifat kekurangan akan diperbaiki dan yang sudah baik diberikan reinforcement sehingga semua temuan dapat dikembangkan pada KBM selanjutnya. Tujuan penelitian adalah ingin mengkaji penerapan RKA dan ingin mengetahui supervisi kunjungan kelas dapat meningkatkan pembelajaran bagi guru pada sekolah binaan pada semester genap tahun 2017/2018 di Kabupaten Kuantan Singingi. Subyek peneitian adalah lima orang guru dari lima sekolah binaan. Rancangan penelitian adalah penelitian tindakan sekolah. Hasil pengkajiam pelaksanaan RKA dan RPP untuk setiap guru, secara umum mengalami peningkatan dari refleksi awal sampai dengan siklus II. Pelaksanaan RKA pada siklus I persentase skor rata-rata dari lima sekolah 88,32 (Sesuai) dan siklus II sebesar 97.92 (Sesuai).Untuk PBM pada refleksi awal diperoleh persentase skor rata-rata 62,2 (Kurang sesuai), siklus I sebesar 83,4 (Cukup sesuai) dan pada siklus II diperoleh sebesar 94,6 (Sesuai). Memperhatikan hasil kajian tersebut dapat disimpulkan bahwa proses pelaksanaan supervisi kunjungan kelas untuk peningkatan pembelajaran bagi guru pada sekolah binaan pada semester genap tahun 2017/2018 di Kabupaten Kuantan Singingi telah sesuai dengan RKA yang disusun. Demikian dengan pelaksanaan RPP dalam kegiatan belajar mengajar sesuai dengan RPP yang disusn serta telah mengalami perbaikan dan peningkatan.
\end{abstract}




\section{A. Pendahuluan}

Pembelajaran pada dasarnya merupakan interaksi pendidik (guru) dengan peserta didik (siswa), untuk mencapai tujuan belajar yang diharapkan. Interaksi yang dimaksud sebagai upaya untuk mengarah ke anak didik kedalam proses belajar. Peran guru dalam proses belajar dalam menciptakan kondisi yang mendukung serta memberikan motivasi dan bimbingan kepada peserta didik agar dapat mengembangkan potensinya melalui kegiatan belajar. Melalui perencanaan pembelajaran yang matang untuk kegiatan pembelajaran merupakan salah satu unsur yang sangat bagi guru dalam mencapai tujuan pembelajaran. Artinya perencanaan yang dibuat oleh guru harus sesuai dengan materi yang akan disajikan dan dengan memperhatikan pula karakteristik siswa. Tidak kalah pentingnya guru harus bisa memilih dan menentukan pendekatan, model atau strategi pembelajaran yang akan dipergunakan. Guru harus memikirkan pula produk apa yang akan dihasilkan oleh siswa pada setiap akhir pembelajaran sesuai dengan komptenasi dasar yang dipilih dalam pembelajaran.

Berdasarkan hal tersebut dan berkenaan dengan tugas pokok dan fungsi serta peran Pengawas Sekolah maka dalam implementasi kepengawasan hal itu perlu untuk mendapatkan perhatian yang serius. Sebab mengingat sistem pembelajaran yang dianut di Indonesia adalah Input - Proses - Out put (IPO) hal ini memberikan pemahaman bahwa kegiatan pembelajaran sangat berpengaruh terhadap out put siswa. Untuk mengetahui sejauh mana pengembangan pelaksanaan pembelajaran di kelas yang dilakukan oleh guru, maka untuk mengetahui perkembangan tersebut dapat melalui kegiatan supervisi kegiatan pembelajaran atau supervisi kunjungan kelas. Supervisi merupakan salah satu kegiatan implementasi manajemen sekolah maka kegiatan tersebut dapat dilakukan oleh
Kepala Sekolah atau Pengawas Sekolah. Soetjipto dan Raflis Kosasi mengemukakan supervisi pendidikan yaitu semua usaha yang dilakukan oleh supervisor untuk memberikan bantuan kepada guru dalam memperbaiki pembelajaran.

Supervisi kegiatan pembelajaran yang mengacu pada standar proses merupakan salah satu tugas pokok dan fungsi Pengawas Sekolah atau Pengawas Mata Pelajaran. Kegiatan kepengawasan yang bersifat rutin ini saya lakukan di lima sekolah binaan pada semester genap tahun pembelajaran 2017/2018 sesuai dengan program kerja yang telah disusun. Tepatnya kegiatan supervisi kunjungan kelas saya laksanakan pada hari Selasa, 2 Januari 2018 di SMPN 1 Pucuk Rantau dan SMPN 3 Singingi Hilir, hari Kamis, 4 Januari 2018 di SMP SATU ATAP Teluk Beringin dan SMPN 1 Singingi Hilir, hari Senin, 8 Januari 2018 di SMPN 2 Hulu Kuantan. Mata pelajaran yang disupervisi terdiri dari mata pelajaran MTK, Bahasa Indonesia, IPS, IPA, PKN.

Setelah hasil supervisi dianalisis dan hasilnya dipergunakan sebagai bahan refleksi awal, menunjukkan bahwa dari lima guru untuk masing-masing guru pada butir-bitir tertentu pada skenario pembelajaran masih terdapat angka/skor 1 (tidak sesuai) dan 2 (kurang sesuai). Ratarata persentase skor penerapan perencanaan KBM untuk masing-masing guru secara kualitatif masuk katagori "Kurang sesuai". Memperhatikan kondisi kegiatan pembelajaran tersebut maka dirasa perlu untuk dilakukan perbaikan dengan harapan guru dapat meningkatkan atau mengembangkan kegiatan pembelajarannya. Upaya untuk memperbaiki kegiatan pembelajaran tersebut yaitu melalui penerapan supervisi kunjungan kelas dengan memberikan penguatan (reinforcement). Bentuk upaya perbaikan kegiatan pembelajaran adalah 
kegiatan Penelitian Tindakan Sekolah (PTS).

\section{B. Landasan Teoritis}

\section{Pengertian Supervisi}

Dilihat dari sudut pandang etimologi supervisi berasal dari kata super dan vision yang masing-masing kata itu berarti atas dan penglihatan. Jadi secara etimologis, supervisi adalah penglihatan dari atas. Pengertian itu merupakan arti kiasan yang menggambarkan suatu posisi dimana yang melihat berkedudukan lebih tinggi dari pada yang dilihat. Hal ini dapat diartikan bahwa kegiatan supervisi dilakukan oleh atasan kepada bawahan.

Supervisi pendidikan muncul karena adanya kebutuhan guru untuk mendapatkan bantuan mengatasi berbagai problem yang menyulitkan guru dalam melaksanakan proses pembelajaran. Guru membutuhkan bimbingan agar ketika melaksanakan proses pembelajaran dapat berlangsung secara maksimal, efektif dan memberikan hasil yang maksimal bagi siswa. Bimbingan tersebut dapat berupa pengembangan design instrukstional, pemilihan stratgi dan metode pembelajaran serta bagaimana dalam mempersiapkan guru agar dapat melaksanakan pembelajaran dengan baik. Pada prinsipnya supervisi adalah bantuan memecahkan masalah pembelajaran yang diberikan kepada guru agar dapat meningkatkan proses pembelajaran di kelas dan dapat memberikan hasil pembelajaran secara maksimal pula.

Dalam Daftar Istilah pada buku yang

ditulis oleh Rusman (2011), ia mengakatan supervisi pembelajaran adalah bantuan dan pelayanan yang diberikan kepada guru agar mau terus belajar, meningkatkan kualitas pembelajarannya, menumbuhkan kreativitas guru, memperbaiki besamasama dengan cara melakukan seleksi diri dan revisi tujuan-tujuan pendidikan, bahan pengajaran. Model dan metode pengajaran, dan evaluasi pengajaran untuk meningkatkan kualitas pembelajaran, pendidikan dan kurikulum dalam pekembangan dari belajar mengajar dengan baik agar memperoleh hasil yang lebih baik.

\section{Tujuan Supervisi}

Memahami pengertian supervisi sebagaimana diuraikan di atas, pada dasarnya tujuan supervisi adalah memberikan bantuan memecahkan kesulitan didalam proses pembelajaran yang dilakukan oleh guru. Namun demikian berkenaan dengan tujuan supervisi Depdiknas (1986, 1994, 1995, dalam Sri Banun Muslim, 2010) menyebutkan sasaran utama dari pelaksanaan supervisi tersebut adalah peningkatan kemampuan profesional guru. Kemudian Feter F. Olivia (1984) menguraikan lebih substansional bahwa tujuan supervisi pembelajaran adalah :

1. Membantu guru dalam meningkatkan proses belajar mengajar;

2. Membantu guru dalam menterjemahkan dan mengembangkan kurikulum, dalam proses belajar menajar;

3. Membantu sekolah (guru) dalam mengembangkan staf.

Selanjutnya Glickman (1981, dalam Sri Banun Muslim, 2010) mengemukan bahwa tujuan supervisi pengajaran adalah membantu guru bagaimana belajar meningkatkan kemampuan mereka sendiri guna mencapai tujuan pembelajaran yang telah ditetapkan bagi siswa-siswanya. Pada hakeketnya, tujuan akhir dari kegiatan supervisi pendidikan adalah untuk memperbaiki guru dalam hal proses belajar mengajar agar tercapai kualitas proses belajar mengajar dan meningkatkan kualitas hasil belajar siswa. 
Merujuk pendapat di atas tentang tujuan supervisi pembelajaran dapat disimpulkan bahwa supervisi pembelajaran adalah bantuan yang diberikan kepada guru oleh supervisor untuk membelajarkan dirinya mengatasi dan memecahkan kesulitan yang di hadapi dalam proses pembelajaran sehingga dapat mencapau tujuan pembelajaran yang telah ditetapkan. Bantuan yang diberikan guru oleh supervisor mengandung makna bahwa bantuan pemecahan kesulitan itu juga sebagai upaya membelajari guru agar bisa memecahkan kesluitan dalam proses pembelajaran dan dilakukan secara terus menerus. Jadi bukan berarti setiap ada kesulitan dalam proses pembelajaran selalu meminta bantuan supervisor untuk memecahkannya. Dengan kata lain proses belajar yang telah dialami dapat meningkatkan dan mengembangkan kemampuan pembelajaran profesi diri.

\section{Supervisi Kujungan Kelas}

Dari berbagai teknik supervisi pembelajaran, seorang supevisor dapat menggunakan teknik supervisi kunjungan kelas sebagai upaya peningkatan kualitas pembelajaran bagi guru. Berkenaan dengan supervisi kunjungan kelas Haris (1985, Alfonso dkk., 1981, Oliva, 1984 dalam Sri Banun Muslim, 2010) disebutkan kunjungan kelas adalah kegiatan seorang supervisor ke kelas pada saat guru sedang mengajar, artinya seorang supervisor menyaksikan dan mengamati guru mengajar.

Kemudian Pidarta (2009) membagi supervisi kunjungan kelas menjadi lima bagian yaitu (1) Tujuan teknik supervisi kunjungan kelas; (2) Ciri-ciri teknik itu; (3) Proses supervisi; (4) Kebaikan tekni, dan (5) Kelemahan teknik itu. Memahami uraian supervisi kunjungan kelas di atas dan dikaitkan kegiatan Penelitian Tindakan sekolah (PTS) yang dilakukan adalah pelaksnaan supervisi kunjungan kelas untuk memperoleh data obyektif melalui pengamatan selama proses pembelajaran berlangsung. Data yang diperoleh dari pengamatan pada dasarnya meliputi tiga katagori yaitu baik sekali, cukup baik dan kurang.

Data hasil observasi proses pembelajaran yang dipandang cukup baik dan kurang akan diperbaiki melalui perbincangan antara supervisor (pengawas peneliti) dengan guru yang bersangkutan. Pemecahan masalah/kesluitan yang dihadapi dipecahkan bersama. Pada sisi lain pengawas peneliti memberikan penguatan (reinforcement) kepada guru bahwa dirinya memiliki kemampuan untuk memperbaiki proses pembelajaran yang lebih berkualitas. Pemberian reinforcement tidak hanya pada sisi kekurangan yang ada pada guru tetapi kelebihan yang sudah dilakukan dalam proses pembelajaran perlu diberikan penguatan. Tujuannya adalah agar guru tidak mengalami kemunduran terhadap proses pembelajaran yang telah dilakukan seara baik. Kondisi yang telah baik itu minimal dipertahankan.

\section{Pengertian Pembelajaran}

Untuk memahami pengertian pembelajaran secara obyektif utamanya pengertian belajar di sekolah maka dirasa perlu dipikirkan dan dirumuskan secara jelas mengenai pengertian belajar. Sudah banyak dijelaskan tentang pengertian belajar oleh para ahli psikologi belajar atau psikologi pendidikan. Salah satu di antaranya Jackson (1991, dalam Rusman, 2011) mengatakan bahwa belajar merupakan proses membangun pengetahuan melalui transformasi pengalaman, sedangkan pembelajaran merupakan upaya yang sistematis dan sistematis dalam menata lingkungan belajar guna menumbuhkan dan mengembangkan belajar peserta didik. Peroses belajar itu sendiri bersifat individual dan kontekstual, artinya proses belajar tersebut terjadi dalam diri individu 
sesuai dengan perkembangan dan lingkungannya. Lebih lanjut dikatakan bahwa belajar merupakan indikator berhasil tidaknya pembelajaran.

Memperhatikan pendapat tersebut dapat dipahami bahwa perubahan yang dialami seseorang setelah mengalami belajar adalah banyak sekali sifat maupun jenisnya. Namun demikian perubahan tersebut adalah perubahan dalam arti belajar. Dengan demikian perubahan tingkah laku itu bisa terjadi karena kesadaran, bersifat kontinyu dan fungsional, bersifat positif dan aktif, bersifat sementara, belajar dengan tujuan yang jelas dan terarah dan perubahan yang bersifat menyeluruh dan mencakup semua aspek tingkah laku.

Jadi belajar merupakan berubahan perilaku seseorang yang pada mulanya tidak tahu kemudian menjadi tahu melalui proses interaksi dengan lingkungan atau berinteraksi dengan dirinya sendiri yang hal itu membangun pengalaman yang mengandung pengetahuan untuk membelajarkan diri mencapai tingkat kedewasaan sesuai dengan tingkat perkembangan diri dan lingkungannya yang pada gilirannya mampu melakukan belajar dengan gaya belajarnya sendiri.

\section{Kegiatan Belajar Mengajar Sebagai Proses}

Merujuk pada penegrtian belajar di atas yang pada prinsipnya adalah sebuah proses perubahan perilaku dari tidak tahu kemudian menjadi tahu hal ini dapat dimaknai bahwa seseorang untuk bisa mencapai tingkat perkembangan diri harus melalui proses interaksi antara diri dengan lingkungannya dan atau dengan dirinya sendiri. Pencapaian tingkat perkembanganm bagi seseorang itu melalui sebuah proses yang dinamakan pembelajaran. Pembelajaran dapat dimaknai sebagai sebuah proses membelajarkan diri sendiri atau orang lain (siswa). Dengeng (1993) mengemukakan bahwa pembelajaran merupakan upaya untuk membelajarkan siswa. Sedangkan Rusman (2011) mengemukakan bahwa pembelajaran pada hakekatnya merupakan suatu proses interaksi antara guru dengan siswa, naik interaksi secara langsung seperti kegiatan tatap muka maupun secara tidak langsung, yaitu dengan menggunakan berbagai media pembelajaran.

Pendapat tersebut bahwa pembelajaran mengandung pengertian kegiatan memilih, mengembangkan, menetapkan, penggunaan pendekatan, metode atau strategi sebagai upaya untuk pencapaian tujuan pembelajaran yang telah ditetapkan. Dalam kegiatan pembelajaran, hal ini telah disusun dalam perencanaan yang sistematis dan penyusunannya sebelum pembelajaran dilaksanakan. Untuk pelaksanaan kegiatan pembelajaran harus tetap berdasar pada perencanaan yang telah disusun. Sedang implementasi pendekatan, model, metode atau strategi pembelajaran harus tetap dalam koridor pendekatan scientific. Artinya dalam kegiatan pembelajaran di kelas harus memenuhi kaidah-kaidah keilmuan dan keilmihan.

Pemahaman pembelajaran berkaitan Penelitian Tindakan Sekolah (PTS) adalah sebuah efektifitas kegiatan belajar mengajar sebagai upaya membelajarkan siswa yang dilakukan oleh guru di kelas yang pelaksanaan pembelajarannya berdasarkan skenario perencanaan pembelajaran yang telah disusun sebelumnya. Sedangkan kegiatan PTS itu sendiri merupakan kegiatan untuk meningkatkan kegiatan pembelajaran guru melalui kegiatan supervisi kunjungan kelas yang dilakukan oleh supervisor (pengawas peneliti). Dalam hal ini peran dan fungsi supervisor adalah memberikan bantuan kepada guru untuk memperbaiki kegiatan pembelajaran utamanya terhadap kekurangan atau kesulitan yang ditemukan 
selama kegiatan pembelajaran berlangsung.

\section{Kerangka Berfikir}

Kerangka berpikir di dalam penelitian sangat diperlukan. Hal ini dimaksud agar tahapan penelitian yang dilakukan jelas dan lebih memudahkan melakukan tindakan. Kerangka berpikir yang dipergunakan untuk PTS tentang peningkatan proses pembelajaran melalui supervisi kunjungan kelas adalah kerangka berpikir dua siklus. Siklus pertama guru akan melaksanakan proses pembelajaran sebagaimana RPP yang telah disusun dan tidak banyak mengalami revisi dari hasil pertemuan awal bersama Pengawas peneliti. Artinya RPP yang telah dilakukan penilaian oleh Pengawas peneliti sudah sesuai dengan materi pelajaran. Demikian halnya dengan metode dan penggunaan media pembelajaran. Lebih lanjut tinggal melihat bagaimana penerapan di dalam proses pembelajaran.

Untuk siklus ke dua, Pengawas peneliti melakukan evaluasi hasil observasi di kelas dan evaluasi dlakukan bersama dengan guru yang bersangkutan. Temuan yang yang baik maupun kurang lebih lanjut diberikan penguatan untuk perbaikan pada proses pembelajaran berikutnya. Kerangka berpikir penelitian dalam skematik sebagai berikut:

Diskripsi skematik karangka berpikir adalah sebagai berikut:

1. Kondisi awal adalah hasil refleksi supervisi KBM sebelum dilakukan penelitian tindakan

2. Berdasakan hasil refleksi awal maka dirasakan perlu untuk dilakukan perbaikan. Perbaikan dilakukan penelitian tindakan malalui penerapan supervisi kunjungan kelas.

3. Penelitian tindakan menggunakan dua siklus.

4. Pengawas peneliti bersama guru nelakukan pertemuan awal untuk mengkaji RPP sebelum KBM dilaksanakan.

5. Siklus pertama, pengawas peneliti melakukan kunjungan kelas untuk pengamatan KBM berdasar RPP yang telah disusun guru.

6. Pengawas peneliti menyampaikan data hasil observasi baik yang bersifat kelebihan atau kekurangan yang lebih lanjut dipecahkan bersama untuk dicari solusinya. Solusi yang dipergunakan untuk perbaikan KBM siklus II adalah pemebrikan reiforcement 
memberikan reinforcement $\mathrm{Hal}$ ini telah disepakati oleh pengawas dan guru.

7. Siklus ke dua, pengawas peneliti melakukan kunjungan kelas untuk pengamatan KBM berdasar RPP yang telah disusun guru dan telah mendapatkan reinforcement.

8. Pengawas peneliti menyampaikan data hasil temuan observasi baik yang bersifat kelebihan atau kekurangan lebih lanjut dipecahkan bersama untuk dicari solusinya untuk perbaikan dan peningkatan KBM berikutnya.

9. Pada kondisi akhir diharapkan ada peningkatan $\mathrm{KBM}$ dan mengacu pada pengalaman KBM sebagaimana telah dilakukan observasi Pengawas peneliti melalui PTS.

\section{Metode Penelitian}

\section{Subyek, Tempat dan Waktu Penelitian}

\begin{tabular}{|c|l|l|l|}
\hline 3 & $\begin{array}{l}\text { Desti Marlena, } \\
\text { S.E }\end{array}$ & $\begin{array}{l}\text { SMP SATU } \\
\text { ATAP Teluk } \\
\text { Beringin }\end{array}$ & IPS \\
\hline 4 & $\begin{array}{l}\text { Suryani Ramli, } \\
\text { S.Pd. }\end{array}$ & $\begin{array}{l}\text { SMPN 1 } \\
\text { Singingi } \\
\text { Hilir }\end{array}$ & IPA \\
\hline 5 & Nofrizal, S.Sos & $\begin{array}{l}\text { SMPN 1 } \\
\text { Hulu } \\
\text { Kuantan }\end{array}$ & PKN \\
\hline
\end{tabular}

\section{b. Tempat Penelitian}

Mengingat kegiatan PTS adalah tentang peningkatan kegiatan pembelajaran di kelas, maka untuk tempat penelitian di sekolah masing-masing guru yang dikenai sasaran penelitian.

c. Waktu Penelitian

Penelitian Tindakan Sekolah ( PTS) dilakukan pada semester genap tahun pelajaran 2017/2018 dalam kurun waktu 3 bulan. Diawali bulan Februari sampai dengan April 2018. Waktu kegiatan diatur sebagaimana pada tabel di bawah ini :

Tabel 2. Alokasi Waktu Pelaksanaan dikenai sasaran penelitian. Guru yang menjadi sasaran penelitian adalah guru mata pelajaran di sekolah binaan sejumlah 5 orang. Masing-masing guru memegang mata pelajaran MTK, Bahasa Indonesia, IPS, IPA, PKN. Guru-guru yang dimaksud sebagai berikut :

Tabel 1. Nama-Nama Guru Sasaran Supervisi Kunjungan Kelas Dalam PTS

\begin{tabular}{|c|c|c|c|}
\hline No. & Nama Guru & $\begin{array}{c}\text { Asal } \\
\text { Sekolah }\end{array}$ & $\begin{array}{c}\text { Mata } \\
\text { Pelajaran }\end{array}$ \\
\hline 1 & $\begin{array}{l}\text { Yusri Yulianti, } \\
\text { S.Pd. }\end{array}$ & $\begin{array}{l}\text { SMPN } \\
\text { Pucuk } \\
\text { Rantau }\end{array}$ & MTK \\
\hline 2 & $\begin{array}{l}\text { Musyayaroh, } \\
\text { S.Pd. }\end{array}$ & $\begin{array}{l}\text { SMPN } \\
\text { Singingi } \\
\text { Hilir }\end{array}$ & $\begin{array}{l}\text { Bahasa } \\
\text { Indonesia }\end{array}$ \\
\hline
\end{tabular}

\begin{tabular}{|c|c|c|c|}
\hline No. & Bulan & Jenis Kegiatan & Ket. \\
\hline 1 & Februari & $\begin{array}{c}\text { 1. Observasi } \\
\text { 2. Menysusun } \\
\text { instrumen } \\
\text { penelitian }\end{array}$ & \\
\hline 2 & Maret & $\begin{array}{c}\text { Pengumpulan data } \\
\text { hasil : } \\
\text { 1. SIKLUS I } \\
\text { 2. SIKLUS II }\end{array}$ & \\
\hline 3 & April & $\begin{array}{c}\text { Penyusunan } \\
\text { Laporan Penelitian }\end{array}$ & \\
\hline
\end{tabular}

\section{Prosedur dan Rancangan Penelitian}

a.Prosedur Penelitian

Prosedur penelitian merupakan tahapan penelitian yang akan dilaksanakan sesuai dengan perencanaan yang telah disusun. Prosedur penelitian yang akan dilaksanakan sebagai berikut: 
a) Melaksanakan observasi awal untuk memperoleh refleksi awal. Hasil refleksi untuk dipertimbangankan perlu atau tidak dilakukan penelitian.

b) Menetapkan rancangan penelitian yaitu Penelitian Tindakan Sekolah (PTS).

c) Menyiapkan hal-hal yang diperlukan dan harus dilakukan dalam penelitian yaitu sebagai berikut:

1) Menyusun skenario tindakan;

2) Menyiapkan fasilitas dan sarana pendukung;

3) Menyiapkan instrumen pengumpul dan analisis data.

4) Menentukan dan menetapkan jumlah tindakan yaitu sebanyak 2 siklus.

d) Menentukan tahapan tiap siklus meliputi perencanaan (planning), tindakan (acting), Observasi (observation) dan refleksi (reflecting).

\section{Tahapan Siklus I}

\section{- Perencanaan (Planning)}

Sebelum melaksanakan kegiatan penelitian terlebih dahulu menyusun Rencana Kepengawasan Akademik (RKA). RKA yang disusun meliputi RKA siklus I dan II yaitu sebagai berikut:

\section{a) RKA siklus I}

Tabel 3. Skenario Kegiatan Siklus I Skenario

\begin{tabular}{|c|l|l|}
\hline No. & \multicolumn{1}{|c|}{ Aspek kegiatan } & Waktu \\
\hline A & Pendahuluan & $\begin{array}{l}\text { Maret } \\
2018\end{array}$ \\
\hline & $\begin{array}{l}\text { 1. Pengawas peneliti membalas } \\
\text { salam guru, kemudian } \\
\text { mempersilahkan }\end{array}$ & $\begin{array}{l}\text { Maret } \\
2018\end{array}$ \\
\hline & $\begin{array}{l}\text { duduk di ruang yang telah } \\
\text { disediakan. }\end{array}$ & $\begin{array}{l}\text { Maret } \\
2018\end{array}$ \\
\hline & $\begin{array}{l}\text { 2. Pengawas peneliti } \\
\text { mendengarkan dengan }\end{array}$ & $\begin{array}{l}\text { Maret } \\
2018\end{array}$ \\
\hline
\end{tabular}

\begin{tabular}{|c|c|c|}
\hline & seksama konsultasi guru & \\
\hline & $\begin{array}{c}\text { tentang kesulitan } \\
\text { pengembangan KBM }\end{array}$ & $\begin{array}{l}\text { Maret } \\
2018\end{array}$ \\
\hline & $\begin{array}{l}\text { 3. Pengawas peneliti } \\
\text { mengidentifikasi kesulitan } \\
\text { yang dihadapi guru }\end{array}$ & $\begin{array}{l}\text { Maret } \\
2018\end{array}$ \\
\hline & $\begin{array}{l}\text { untuk dibahas secara } \\
\text { khusus. }\end{array}$ & $\begin{array}{l}\text { Maret } \\
2018\end{array}$ \\
\hline \multirow[t]{16}{*}{ B } & Kegiatan Inti & $\begin{array}{l}\text { Maret } \\
2018\end{array}$ \\
\hline & 1. Tahap Awal & $\begin{array}{l}\text { Maret } \\
2018\end{array}$ \\
\hline & $\begin{array}{l}\text { a. Pengawas peneliti } \\
\text { memberikan kesempatan guru } \\
\text { untuk memilih }\end{array}$ & $\begin{array}{l}\text { Maret } \\
2018\end{array}$ \\
\hline & $\begin{array}{l}\text { Alternatif pemecahan } \\
\text { kesulitan yang dihadapi. }\end{array}$ & $\begin{array}{l}\text { Maret } \\
2018\end{array}$ \\
\hline & $\begin{array}{l}\text { b. Pengawas peneliti } \\
\text { menawarkan alternatif } \\
\text { pemecahan kesulitan }\end{array}$ & $\begin{array}{l}\text { Maret } \\
2018\end{array}$ \\
\hline & yang dihadapi guru. & $\begin{array}{l}\text { Maret } \\
2018\end{array}$ \\
\hline & $\begin{array}{l}\text { c. Pengawas peneliti } \\
\text { melakukan shering dengan } \\
\text { guru memilih alterna- }\end{array}$ & $\begin{array}{l}\text { Maret } \\
2018\end{array}$ \\
\hline & $\begin{array}{l}\text { tif pemecahan kesulitan } \\
\text { yang dihadapi guru }\end{array}$ & $\begin{array}{l}\text { Maret } \\
2018\end{array}$ \\
\hline & $\begin{array}{l}\text { d. Pengawas peneliti } \\
\text { menyampaikan materi } \\
\text { supervisi kunjungan kelas }\end{array}$ & $\begin{array}{l}\text { Maret } \\
2018\end{array}$ \\
\hline & $\begin{array}{l}\text { e. Pengawas peneliti } \\
\text { menyampaikan teknik } \\
\text { pengamatan supervisi }\end{array}$ & $\begin{array}{l}\text { Maret } \\
2018\end{array}$ \\
\hline & kunjungan kelas & $\begin{array}{l}\text { Maret } \\
2018\end{array}$ \\
\hline & $\begin{array}{l}\text { f. Pengawas peneliti } \\
\text { menjelaskan kelengkapan guru } \\
\text { dalam proses }\end{array}$ & $\begin{array}{l}\text { Maret } \\
2018\end{array}$ \\
\hline & pembelajaran. & $\begin{array}{l}\text { Maret } \\
2018\end{array}$ \\
\hline & $\begin{array}{l}\text { g.Pengawas peneliti } \\
\text { memberi kesempatan guru } \\
\text { untuk bertanya }\end{array}$ & $\begin{array}{l}\text { Maret } \\
2018\end{array}$ \\
\hline & $\begin{array}{l}\text { 2. Tahap pelakasanaan } \\
\text { supervisi kunjungan kelas } \\
\text { (me nggunakan }\end{array}$ & $\begin{array}{l}\text { Maret } \\
2018\end{array}$ \\
\hline & instrumen pengamatan) & Maret \\
\hline
\end{tabular}




\begin{tabular}{|c|c|c|}
\hline & & 2018 \\
\hline & & $\begin{array}{l}\text { Maret } \\
2018\end{array}$ \\
\hline & 3. Tahap balikan & $\begin{array}{l}\text { Maret } \\
2018\end{array}$ \\
\hline & $\begin{array}{l}\text { a. Pengawas peneliti } \\
\text { menyampaikan kelebihan } \\
\text { dan kekurangan guru }\end{array}$ & $\begin{array}{l}\text { Maret } \\
2018\end{array}$ \\
\hline & $\begin{array}{l}\text { dalam proses } \\
\text { pembelajaran }\end{array}$ & $\begin{array}{l}\text { Maret } \\
2018\end{array}$ \\
\hline & $\begin{array}{l}\text { b. Pengawas peneliti tukar } \\
\text { pendapat untuk memperbaiki } \\
\text { kekurangan }\end{array}$ & $\begin{array}{l}\text { Maret } \\
2018\end{array}$ \\
\hline & $\begin{array}{l}\text { dan meningkatkan yang } \\
\text { sudah baik }\end{array}$ & $\begin{array}{l}\text { Maret } \\
2018\end{array}$ \\
\hline & $\begin{array}{l}\text { c. Pengawas peneliti } \\
\text { menawarkan pertemuan ke dua } \\
\text { un tuk pertmuan }\end{array}$ & $\begin{array}{l}\text { Maret } \\
2018\end{array}$ \\
\hline & awal siklus II & $\begin{array}{l}\text { Maret } \\
2018\end{array}$ \\
\hline & $\begin{array}{l}\text { d. Pengawas peneliti } \\
\text { menyampaikan terima kasih } \\
\text { atas niat baik dan }\end{array}$ & $\begin{array}{l}\text { Maret } \\
2018\end{array}$ \\
\hline & $\begin{array}{l}\text { perhatian yang tinggi guru } \\
\text { untuk melaku kan perbaikan } \\
\text { KBM dan }\end{array}$ & $\begin{array}{l}\text { Maret } \\
2018\end{array}$ \\
\hline & $\begin{array}{l}\text { pertemuan diakhiri } \\
\text { dengan jawaban salam dari } \\
\text { guru }\end{array}$ & $\begin{array}{l}\text { Maret } \\
2018\end{array}$ \\
\hline \multirow[t]{7}{*}{$\mathbf{C}$} & Penutup & $\begin{array}{l}\text { Maret } \\
2018\end{array}$ \\
\hline & $\begin{array}{l}\text { a. Pengawas peneliti } \\
\text { menegaskan kembali inti } \\
\text { materi supervisi }\end{array}$ & $\begin{array}{l}\text { Maret } \\
2018\end{array}$ \\
\hline & kunjungan kelas & $\begin{array}{l}\text { Maret } \\
2018\end{array}$ \\
\hline & $\begin{array}{l}\text { b. Pengawas peneliti } \\
\text { meminta salinan RPP yang } \\
\text { KBM- nya untuk }\end{array}$ & $\begin{array}{l}\text { Maret } \\
2018\end{array}$ \\
\hline & supervisi kunjungan kelas & $\begin{array}{l}\text { Maret } \\
2018\end{array}$ \\
\hline & $\begin{array}{l}\text { c. Pengawas peneliti } \\
\text { bermusyawarah menetapkan } \\
\text { jadwal supervisi }\end{array}$ & $\begin{array}{l}\text { Maret } \\
2018\end{array}$ \\
\hline & Kunjungan kelas & $\begin{array}{l}\text { Maret } \\
2018\end{array}$ \\
\hline
\end{tabular}

\begin{tabular}{|c|c|}
\hline $\begin{array}{l}\text { d. Pengawas peneliti } \\
\text { menyampaikan terimakasih } \\
\text { atas perhatian guru }\end{array}$ & $\begin{array}{l}\text { Maret } \\
2018\end{array}$ \\
\hline $\begin{array}{l}\text { dan kemauan yang tinggi } \\
\text { untuk meningkatkan KBM dan } \\
\text { ditutup }\end{array}$ & $\begin{array}{l}\text { Maret } \\
2018\end{array}$ \\
\hline $\begin{array}{l}\text { dengan balasan salam } \\
\text { guru. }\end{array}$ & $\begin{array}{l}\text { Maret } \\
2018\end{array}$ \\
\hline
\end{tabular}

\section{- Tindakan (Acting)}

Tindakan (acting) adalah pelaksanaan penelitian dalam kegiatan supervisi kunjungan kelas dengan menggunakan instrumen pengamatan yang telah disediakan. Instrumen yang dipergunakan adalah instrumen berkenaan dengan tindakan penelitian dan berkenaan dengan KBM yang dilakukan oleh guru dan instrumen berkenaan dengan proses tindakan penelitian yang dituangkan dalam RKA.

Untuk tindakan yang dilaksanakan dalam penelitian sebagaimana dituangkan dalam RKA meliputi tiga tahapan yaitu tahap awal, tahap implementasi pembelajaran dan tahap balikan.

\section{- Pengamatan (observation)}

Pengamatan dilakukan oleh Kolaborator dan Pengawas Peneliti. Kolaborator mengamati implementasi RKA dengan menggunakan instrumen yang telah ditentukan yang dalam prosesnya dilaksanakan oleh Pengawas Peneliti. Sedang pada kegiatan supervisi kunjungan kelas yakni kegiatan KMB dilakukan oleh Pengawas Peneliti.

Observasi dilakukan oleh Kepala Sekolah masing-masing sekolah yang dikenai penelitian. Hai dilakukan dengan tujuan untuk efisiensi baik tenaga maupun pendanaan. Sedang Pengawas peneliti melakukan pengamatan KBM guru. 
- Refleksi (reflektion)

Refleksi yang dimaksud adalah balikan hasil pengamatan yang sudah dilakukan oleh pengawas peneliti maupun kolaborator. Hasil pengamatan oleh pengawas peneliti merupakan refleksi pelaksanaan KBM oleh guru. Untuk refleksi hasil pengamatan kolaborator adalah refleksi hasil pengamatan terhadap implementasi RKA.

Hasil pengamatan dari dua instrumen tersebut akan diperoleh dua jenis temuan yaitu kekurangan dan kelebihan dari masing-masing kegiatan. Kekurangan yang ada dari masing-masing kegiatan lebih lanjut akan diperbaiki pada siklus II. Sedang untuk kelebihan minimal akan dipertahankan atau jika memungkinkan bisa ditingkatkan.

\section{Teknik Pengumpulan Data}

Pengumpulan data penelitian menggunakan teknik pengamatan (observasi). Baik untuk implementasi RKA maupun KBM. Sebagaimana dijelaskan di atas bahwa untuk pengamatan implementasi RKA dilakukan oleh kolaborator dan untuk pengamatan KBM dilakukan oleh Pengawas Peneliti.

\section{E. Hasil Penelitian}

Untuk memaparkan data hasil penelitian akan disajikan dalam tiga tahapan yaitu tahap hasil refleksi awal, hasil siklus I dan berikutnya hasil siklus II.

\section{Data Hasil Refleksi awal}

Data hasil refleksi awal adalah data yang diperoleh dari hasil pengamatan pada proses pembelajaran (KBM) yang dilakukan sebelum penelitian dilakukan.

Sebagaimana tabel 7, telah digambarkan bahwa untuk masing- masing guru pada butir-bitir tertentu pada skenario pembelajaran masih terdapat angka/skor 1 (tidak sesuai) dan 2 (kurang sesuai). Rata-rata persentase skor penerapan perencanaan $\mathrm{KBM}$ untuk masingmasing guru secara kualitatif masuk katagori "Kurang sesuai". Dengan kata lain bahwa pembelajaran masih berlangsung kurang efektif karrena kurang sesuai dengan RPP yang disusun.

\section{Data hasil Penelitian}

Hasil pengamatan siklus I baik yang dilakukan oleh Pengawas peneliti maupun oleh kolaborator yaitu :

1. Data hasil pengamatan Pelaksanaan RKA siklus I dan II

2. Data hasil pengamatan proses pembelajaran guru.

Berikut ini tabel hasil pengamatan untuk masing-masing kegiatan : pada siklus I, perolehan jumlah skor untuk lima sekoah masing-masing 89,02 kecuali SMPN 1 Pucuk Rantau mencapai 87,50. Untuk besaran skor persentase masing-masing sekolah mengalami peningkatan dari siklus I. SMPN 1 Pucuk rantau siklus I rata-rata skor persentase 87,50 dan siklus II mencapai 95,64. SMPN 3 Singingi Hilir siklus I rata-rata skor persentase 89,02 dan siklus II mencapai 99,24. SMP SATU ATAP Teluk Beringin siklus I rata-rata skor persentase 89,02 dan siklus II mencapai 97,73. SMPN 1 Singingi Hilir siklus I rata-rata skor persentase 89,02 dan siklus II mencapai 97,73. Dan SMPN 1 Hulu Kuantan siklus I rata-rata skor persentase 89,02 dan siklus II mencapai 99,24. Memperhatikan perkembangan perolehan rata-rata skor persentase dapat diberikan 
pemahaman bahwa ada peningkatan kesesuaian pelaksanaan RKA pada masingmasing sekolah baik secara kuantitatif maupun kualitatif.

\section{F. Kesimpulan}

Pelaksanaan RKA secara menyeluruh pada siklus I, perolehan jumlah skor untuk lima sekoah masingmasing 89,02 kecuali SMPN 1 Pucuk Rantau mencapai 87,50. Untuk besaran skor persentase masing-masing sekolah mengalami peningkatan dari siklus I. SMPN 1 Pucuk rantau siklus I rata-rata skor persentase 87,50 dan siklus II mencapai 95,64. SMPN 3 Singingi Hilir siklus I rata-rata skor persentase 89,02 dan siklus II mencapai 99,24. SMP SATU ATAP Teluk Beringin siklus I rata-rata skor persentase 89,02 dan siklus II mencapai 97,73. SMPN 1 Singingi Hilir siklus I rata-rata skor persentase 89,02 dan siklus II mencapai 97,73. Dan SMPN 1 Hulu Kuantan siklus I rata-rata skor persentase 89,02 dan siklus II mencapai 99,24. Memperhatikan perkembangan perolehan rata-rata skor persentase dapat diberikan pemahaman bahwa ada peningkatan kesesuaian pelaksanaan RKA pada masing-masing sekolah baik secara kuantitatif maupun kualitatif. Dengan demikian dapat disimpulkan bahwa penerapan supervisi kunjungan kelas untuk peningkatan pembelajaran bagi guru pada sekolah binaan semester genap tahun 2017/2018 di Kabupaten Kuantan Singingi telah sesuai dengan RKA yang disusun.

\section{G. Daftar Pustaka}

Akib, Zainal, 2003. Penelitian Tindakan Kelas. Bandung : Yrama Widya
Daryanto, 2009, Panduan Proses Pembelajaran Kreatif dan Inovatif, Jakarta, AV. Publisher.

Degeng, I Nyoman Sudana,1993, Buku Pegangan Teknologi Pendidikan, Pusat Antar Universitas Untuk Peningkatan dan Pengembangan Aktivitas Instruksional Universitas Terbuka, Depdikbud RI, Dirjen Dikti, Jakarta

Bigge, Morris L., 1976, Learning Theoris for Teacher, Third Edition, Harper and Row Publishers, London, New York

McMahon. And McMahon, 1982. Psychology The Hybryd Science, Illionis : The Dorsey Press

Nawawi, 1981, Administrasi Pendidik, Jakarta, Gunung Agung.

Pidarta, Made, 2009, Supervisi Pendidikan Kontekstual, Jakarta, Rineka Cipta.

Rusman, 2011, Model-Model Pembelajaran Mengembangkan Profesionalisme Guru, Jakarta, Rajawali Pers, RajaGrafindo Persada.

Sri Banun Muslim, 2010, Supervisi Pendidikan Meningkatkan Kualitas Profesioalisme Guru, Alvabeta.

Thantawy R, 1983, Kamus Bimbingan Konseling, Jakarta, Group Economic's Student. 